\title{
Interrelation of Philosophical and Religious Values of Russia and the USA: Historical and Cultural Context*
}

\author{
Olga V. Chistyakova \\ Department of History of Philosophy \\ Faculty of Humanities and Social Sciences \\ Peoples' Friendship University of Russia (RUDN \\ University) \\ 6 Miklukho-Maklaya Street \\ Moscow, Russian Federation1 17198 \\ E-mail: olgachis@yandex.ru
}

\author{
Denis I. Chistyakov \\ STREAM Television Company, JSC \\ 1st Rizhsky Lane, bld. $2 \mathrm{G}$ \\ Moscow, Russia 129626 \\ E-mail: chistyakov.d@gmail.com
}

\begin{abstract}
The article is dedicated to the consideration of the most important philosophical and religious ideas of modern American theology and Russian philosophy of the late $19^{\text {th }}$-early $20^{\text {th }}$ centuries. The author scrutinizes the values and concepts of the Pilgrim Fathers and Eastern Christian Patristics in the historical and philosophical context. Special attention is paid to the unity of meanings of Russian religious philosophy and some religious and philosophical concepts of the modern-day USA. The conceptual provisions of American theologians and philosophers C. Gillis, G. Richardson, and L. Gilkey are reviewed. The author considers Russian religious philosophy as a possible basis for unity and peaceful interaction between the two cultures - Russian and American.
\end{abstract}

Keywords-culture; religion; American theology; Christian anthropology; history of the USA; Russian religious philosophy; Byzantine patristics

\section{INTRODUCTION}

The cultural-axiological dimension of the Russian-United States relations is seen as quite antinomic. The Russian public opinion is dominated by the idea that the USA is so invested in the technological progress that the Americans don't actually reflex on spirituality, soul, religion and other cultural and moral values. At the same time, many Russians share the views of the Russian spiritual Weltanschauung being historically predetermined by the Christian values.

Analysis of the US religious, philosophical and theological literature allows partial overcoming of the aforementioned prejudice. Moreover, the following research builds basic cultural and anthropological values, able to unite two extremes in our countries' worldviews and even serve as an identity basis for the Russian-US cultures.

\section{RUSSIA AND THE USA: CULTURAL-RELIGIOUS DISCOURSE}

The modern US research, concerning the religious philosophy, links the establishment of the cultural identity

*The publication has been prepared with the support of the "RUDN University Program 5-100" not to the secular but to the religious future of the States. The American researchers are trying to carry out an analysis of the interrelations between the reconstruction of American theology and the spiritual revival of the American nation [1]. Such goals are actually historically justified since the becoming of the United States was largely due to the ideology of the Puritan Pilgrim Fathers.

So, an American mindset comes close to what is known as "the search for the Russian national idea" with the US researchers being immanently relevant to the Russian psychological orientation. It is thus necessary to understand and analyze the country's religious roots in order to identify oneself. Puritan past with its utopic ideas about building the religious state on the North American East Coast with the strong theoretical social-religious basis brought us to the point where the past influences the present and the future.

Russia's cultural history till 1917 shows the similar succession: Russian philosophy found the most significant principles of state structure and national ideology in the provisions of the Orthodox Christian concept (among them are Sobornost, anthropocentrism and harmonious StateChurch relations). The focus of Russian philosophy on personality, on a solution of life-purpose issues, on the disclosure of the existential essence of a person had its origins in the Greek-Byzantine Patristics of the 4th - 8th centuries. Even then the Christian anthropological theory was created, the appeal to which is quite relevant nowadays. This theory erases partially the so-called "civilizational" differences between the West (Europe, the States) and Russia, as it designs the progressive development of the peoples' spiritual culture and the priority of rationalism, not excluding the value of individualism.

The correlation of the Patristics' ideals with the current situation in Russia doesn't mean the copy of an imitation. As well as the conceptual orientation of the American thinkers on religious heritage doesn't mean a call for a literal restoration of the 17 th $-18^{\text {th }}$ centuries theology. Obviously, the theories of the past are not suitable for solving the urgent social issues and are not adequate to the religious situation itself. The Patristics discourse (free from the state and 
political doctrines) makes it possible to understand how applicable this culture is for realizing the creative potential of the modern society as a whole. The American philosophers, in turn, set the goal to comprehend the history of their state and to draw an image of its future in religious categories, which by their moral and humanistic design are able to smooth social and ideological contradictions. For example, the Georgetown University Professor Chester Gillis associates the US culture of the 21 st century with the perception of the Americans' religious identity. According to Professor Gillis, the forthcoming era will witness the dissolution of religious denominations and the contradictions of the believers [2].

Pluralism is the dominant principle of the modern American theological and religious-philosophical literature, demonstrating a wide range of positions, approaches and possible solutions to a sole problem; this principle is hardly feasible in Orthodoxy. The researchers believe pluralism a requirement of time and link it with the experience and selfconsciousness of the Pilgrims. In a sense, today's US spiritual culture sustains the legacy of its religious roots, which were determined by the two following important facts.

First, the Pilgrim Fathers didn't have a shared ideology and didn't set common goals. For the most part, the settlers were Protestants who hoped to create in their Plymouth Colony a religious state based on the unity of Church and State. Yet, the implementation of this "holy experiment" in New England staggered, as it contradicted the basic principles of the other, later colonies, whose idea was to keep Church and State separate. Thus, the religious diversity of the Pilgrims - Puritans, Roman Catholics in Maryland, Quakers in Pennsylvania, etc. - is the evidence of religious pluralism a priori inherent to the American nation.

Secondly, American thinking wasn't initially developed in the context of the "United States". The first colonies, whose lives reflected the plurality of cultures and goals, didn't seek to unite and unify their political and religious tasks. The unification of the colonies, while maintaining the de facto independence of their individual determinations and religious worldviews, was made possible by the fact that cultural diversity and the freedom of thought were partly preserved in a new integrity.

The Pilgrims' religious consciousness was distinguished by the absolutization of their spiritual ideals and the purity of religious principles. The ideas of an ecumenical Church and the formation of a multicultural society, open to everyone, was universal. These ideas were seen as both political and religious. Similar principles may be found in the Byzantine Empire at the dawn of Christianity when the Church Fathers expressed the idea of the catholicity of the Christian Church. These concepts prevailed in Russian religious philosophy of the late 19th - early 20th centuries.

Akin to the Pilgrim Fathers, the Russian philosophers of the aforementioned times disputed about both religious and secular traditions. For some, the ideal society was the earthly one, created entirely by people without God - deified humans, the climax of individuality. For others, the ideal society meant Christian ideas, active faith, the continuation of divine Incarnation in the history of humanity, and the transformation of the earthly life in the light of Christianity [3]. The early Slavophiles - Ivan Kireyevsky and Aleksey Khomyakov among them - justified the urgency to create new social philosophy centered around Church. However, they were convinced, such philosophy should be created in the spirit of Sobornost — altogether, with "Sobornost" defined as "the unity through the gathering" (cf. "E pluribus unum"), free from contradictions, united by the Orthodox faith and values. The Sobornost concept is somehow reminiscent of the pluralist ideas of the Pilgrim Fathers. The history of the development of religious and philosophical concepts at different times and in different countries brings us back to something integral, to a certain bifurcation point, after which the societies divided and went their own ways.

Worth noting that the basic principles for building a religious life, such as pluralism and pragmatism, remain viable concepts in the modern United States as well, although in somewhat mild forms. Comprehending the historical traditions, the modern-day researchers set the task of building a "New American Theology" for the purpose of the cultural identity of the country. The concept of "American theology" implies in this context many freely expressed views on the relationship between society and religion, which are being institutionally developed in the interaction and are open to individual assessments. The modern American Religious and philosophical concepts, based on the calls to create a particular kind of theology, or even a "new" version of God, are diverse and really interesting, so I am to allow myself to dwell on some of them.

\section{AMERICAN THEOLOGY — INNOVATIONS AND TRADITIONS}

American philosophers, engaged in the discourse of rationalizing theology, proceed from the peculiarity of the economic and social life of American society. Theorists, trying to create a "new typology" of God, clearly reflect the trends of the US social structure of the past 70-80 years: technocracy, scientism, absolutization of the political sphere, urbanization. Hence, are the unusual names of God, not acceptable, e.g., in the Orthodox theology: "technogenic God", "political God", "democratic God", "sociotechnical God", etc.

For example, Herbert Richardson sets forth an idea of developing a "proper American theology". His schemes, however, appeal not only to the American philosophical and theological traditions but also to the management theories, IT, progressive technical innovations etc. He believes that a certain period of history, when a society was dominated by religiosity, comes to an end along with the loss of the importance of God for the socialization of an individual under modern conditions. A person will have to live in a rapidly developing technocratic society, which requires the construction of a "new theology" to fill the spiritual void.

Richardson proposes to introduce such "synthetic" categories as "socio-technical God" and "cybernetic God", which, in his opinion, will reflect the relationship between the real world and the human attraction to religious values. 
The philosopher assumes that "socio-technics", i.e., new knowledge by means of which a person receives technical control over society, is a source of many religious problems. According to Richardson, "theology should develop the concept of God which can support the primary reality of the cybernetic world" [4], the world of "systems" and "matrices". Richardson's "socio-technical God" must help everyone to adapt to the world of faceless machines and the coming age of artificial intelligence. However, the author's categorical innovation remains unclear due to the lack of a reasoned theological-philosophical concept. What is the status of "socio-technical God"? How can a person think and comprehend God, stemming from the world of cybernetics and programming? Will this God be an attractive model for today's generation of the young Americans, facing the dilemma of technogenic revolution and personal pursuit of spirituality?

Harvey Cox addresses similar issues. He denies the significance of metaphysical constructions in describing the relationship between man and the transcendent world. The American theologian proposes to use political idioms, since politics, from his point of view, provides importance to human life and thinking. He introduces a new concept of "political God", manifesting Himself in mundane politics and social events, performing a function, similar to the function of Richardson's "socio-technical God". Yet, for H. Cox the main issue is epistemology: how to describe God in secular and positive terms? Would the so expressed Absolution be acceptable for a human being in postmodernity? The author per se recurs to the Patristics works, created in the early centuries of Christianity.

Then the dispute over the possibility to express and describe God was resolved in favor of apophatic theology: a person is able to show and comprehend exactly what God isn't, and what traits don't belong to Him. The positive traits of God are inherent in Him, and the human mind isn't able to know them empirically. Apophatic comprehension of God is super-knowledge, perfect knowledge, acquired, however, not in a rational but in a mystic-contemplative way. Dionysius the Areopagite, Gregory of Nazianzus and Athanasius of Alexandria wrote that the main category, that man seizes at the top of his ascent to God, is the Divine Unknowability. It is impossible to describe God by empirical categories related to the sphere of human experience. American theologians, however, often describe Him just in these definitions and categories, trying to justify their concepts.

Urgent issues and contradictions once again rise from the depths of the history the problem of the human ability to "name" and describe God. It seems that this is due to the persistent need for God-knowing, as people crave to know God to the very limits of the human mind. Langdon Gilkey associates the need to "verbalize" God and His traits with the desire to hear the voice of God in the "world whirlwind" of events. The theologian resorts (just as H. Cox) to the use of biblical concepts and terms. Yet, the American authors themselves note that there isn't much progress made and nothing significantly new has been added to the "verbalization" of God in comparison with the original theological metaphors. L. Gilkey reflects whether the dogmas, postulates, and concepts of Christian doctrine fill the current gaps and void in culture and religion. Most importantly, how can we talk about God in the modern era, "which dominant trend is a cultural and a secular attitude?" [5].

The questions, posed by L. Gilkey, may be partially resolved by the analysis of the works of the early Christian thinkers. The provisions of their teaching were so "humane" that they still retain the importance for modern society. The problems of the possibility of God-knowing and Goddescription were closely associated with the personal development and self-cognition of an individuality, included in the relationship with the Absolution. Greek-Byzantine theologians considered the process of self-identity and the formation of own freedom as coinciding with the processes of knowing God and self-cognition, which was also important for a secular thought. The Eastern theology focused on the cultivation of internal qualities and properties of an individual, the development of his psychological traits. Russian "God-seekers" and Christian anthropologists described this as a "journey to self". This is a process of selfcognition and self-creation through the search for moral ideals, the comparison of own actions with the morality rooted in God.

\section{CONCLUSION}

We believe that some conclusions of rationalized American theology, which highest ideal is the existence of a diverse range of opinions, based on the spirit of unity and cultural identity, are consistent with the provisions of the Russian spiritual tradition and Greek-Byzantine religious philosophy. The concepts of Sobornost and anthropocentrism, formed in the aforementioned teachings, can still influence the spiritual life of peoples on both sides of the Atlantic Ocean. In a today's world, split by globalization, the values of religious culture and philosophy, realistically comprehended and introduced in the social lives of Russian and the USA can become the radical means for resolving many existing contradictions. It is vital to see that our cultural traditions have intersection points - much in the history unites our countries. Perhaps, the basis of Sobornost, described by Russian philosophers and dreamed of by the Pilgrim Fathers, may be found in the norms of morality, culture, and religion, quenched by the spirit of humanism.

\section{REFERENCES}

[1] Sontag F., Roth J. The American Religious Experience. The Roots, Trends, and Future of American Theology. N.Y., 1990.

[2] Gillis Ch. Roman Catholicism in America. N.Y.: Columbia University Press. 1999. P. 277.

[3] Chistyakova O. Russian Religious Philosophy as the Basis for State Identity // Journal of Eurasian Research. Vol. 1. № 1. Washington, DC: American Councils for International Education. 2003.

[4] Richardson H. Toward an American Theology. N.Y.: Harper and Row, 1967. P. 23.

[5] Gilkey L. Naming the Whirlwind: The Renewal of God Language. Indianapolis: Bobbs-Merrill Company, 1969. P. 34. 